\title{
Measuring an Interaction of Sexual Harassment and Employee Job Satisfaction
}

Mafuzah Mohamad ${ }^{1}$, Shahidah Ahmad Suhaimi ${ }^{2}$

${ }^{1,2}$ Department of Management and Human Resource, National Energy University

\begin{tabular}{|c|c|}
\hline ARTICLE INFO & ABSTRACT \\
\hline Article history: & \multirow{10}{*}{$\begin{array}{l}\text { Sexual harassment is an ongoing issue which unlikely to be reported } \\
\text { by the employees who experienced. The sexual provocation towards } \\
\text { employees is likely to be happened at the workplace despite the gender } \\
\text { is. Previous studies revealed that, women in automotive industry are } \\
\text { more likely to expose and experience sexual harassment as the } \\
\text { proportion of women are less in this industry. This paper aims to } \\
\text { investigate sexual harassment relation with employee job satisfaction. } \\
\text { Questionnaires were distributed to employee in automotive industry in } \\
\text { Malaysia. A total of } 204 \text { usable questionnaires were analysed. The } \\
\text { findings indicated that sexual harassment is partially significant with } \\
\text { employee job satisfaction. The result could assist the company in } \\
\text { drafting policies in an organization aiming at minimizing the } \\
\text { occurrence of sexual harassment in workplace environment. }\end{array}$} \\
\hline Received: January 3, 2019 & \\
\hline Revised: February 15, 2019 & \\
\hline Accepted: March 16, 2019 & \\
\hline Keywords: & \\
\hline Sexual Harassment, & \\
\hline Job Satisfaction, & \\
\hline Gender Harassment, & \\
\hline Sexual Coercion, & \\
\hline Unwanted Sexual Attention & \\
\hline
\end{tabular}

Clonflict of Interest:

None

Funding:

None

Corresponding Author: Mafuzah Mohamad, Department of Management \& Human Resource, National Energy University, Malaysia

(C) Mafuzah Mohamad, Shahidah Ahmad Suhaimi

This is an open access article under the CC BY-SA 4.0 international license.

\section{Introduction}

Recently, sexual harassment is a serious concern by most of the people around the globe. According to World of Labour (2015), there are 75 countries that legally against and prohibits sexual harassment in their country (Hersch, 2015). While in Malaysia, in year 2002, Women's Development Collective found that 35\% respondents in their study had experienced sexual harassment. Sexual harassment at working environment is exceptionally unsafe, restrictive, and lengthy which giving a real reason for work environment strain and work disappointment (Sabitha, Norul Huda, \& Roza, 2013). Hutagalung and Ishak, (2012) contended that, sexual harassment is typically regarded as all manifestations of unwanted conduct of a sexual nature, verbal or physical. The Malaysian Code of Practice (1999) deliberately characterizes sexual provocation as any unwanted direct of a sexual nature that may be assumed by; (i) as a circumstance on one's administration, (ii) as an offence or disrespect, or (iii) as a danger to one's well-being.

Job satisfaction is an essential element to study as its significance not only physically but also to the well-being of employees. Previous authors (Alagappar, Lean, David, Ishak, \& Ngeow, 2011; Kenny, Samah, \& Othman, 2011; Sabitha \& Asmak, 2012) studied the relationship between sexual harassment and working environment in Malaysia but it was not known if there was a connection between sexual harassment variables and employee job satisfaction. Based on Chan, Lam, Chow and Cheung (2008), job dissatisfaction may lead to psychological distress.

In a similar vein, Hutagalung and Ishak, (2012) contended that sexual harassment contributed to lower level job satisfaction that leads to employee's work stress. Additionally, sexual harassment adversely affects 
employee job satisfaction (Bond, Punnett, Pyle, Cazeca, \& Cooperman, 2004; L. Fitzgerald, Swan, \& Magley, 1997; Frone, 2000; Whealin, Davies, Shaffer, Jackson, \& Love, 2002).

Automotive industry is one of the main contributors to Malaysia economics. Though, there are very limited studies on sexual harassments in Malaysia focusing on the automotive industry. However, a study found that women were sexually harassed in this industry because of the real concern on the proportion numbers of women less than men in assembly line (Housch \& Collins, 1993). Therefore, it indicated that, there is a higher tendency of sexual harassment occurred in automotive industry.

\subsection{Sexual Harassment}

Sexual harassment is an unwanted behaviour occurred without an approval of the receiver (Kenny et al., 2011). Ismail, Lee, and Chan (2007) inspected the elements that induce sexual provocation at Malaysian working environment. Despite the fact that sexual provocation might include either men or ladies as the exploited person, men have rarely been sexually harassed. According to Harvell (2007), any invasive gestures, unpleasant languages and any exchanges for sexual favour such promotions or better privileges are parts of sexual harassment. This issues becomes a contractual term for granting any benefits by individuals either been done explicitly or implicitly (Sabitha, Asmak, \& Nur Sabrina, 2011). In Malaysia, sexual harassment was described as uninvited behaviour led to a sexual orientation by oral, gestures, visually or psychologically which impacted receiver well-being. (Ministry of Human Resources, 1999).

Sexual harassment is an issue that likely practiced at workplaces (Pradhan-malla, 2005; Sabitha \& Asmak, 2012). Hutagalung and Ishak (2012) noted that, recently this phenomenon has turned into a world issue and becoming common issue in all sectors and industries (Sadruddin, 2013). People also had seen the sexual harassment as an issue (Bingham \& Scherer, 1993) that influences associations (Fitzgerald \& Shullman, 1993).

\subsection{Gender Harassment}

Gender discrimination refers to any actions that prioritize work or giving unfair treatment based on gender (Carr et al., 2012). In line with Leskinen, Rabelo, \& Cortina (2015), the researchers mentioned that most psychological researchers agreed that gender harassment is the utmost type of sexual harassment experienced by women. Moreover, gender harassment also defined as a behaviour that implicates the display of teasing, intimidating and humiliating toward women (O'Connell \& Korabik, 2000; Yusuf, 2010). The scholars also agreed that sexual harassment is prone to ladies due to most women typically have lower position in an organization and the proportion number of women are lower than men. Nevertheless, Compton (2007) argued that sexual harassment does not have to be from opposite sex from the harasser.

However, despite that woman is likely to experience this harassment, the occurrence of sexual harassment to both men and women will lead a hostile work environment. (Willness, Steel, \& Lee, 2007; Connell \& Korabik, 2000). In addition, most of the researchers found that men also experienced sexual harassment and gender harassment. (Rabelo, et. al, 2015).

\subsection{Sexual Coercion}

Leskinen et al. (2015) defined sexual coercion as actions that take place when the harasser offers inducement or job-related threats; such job dismissal in order to force the victim in establishing a sexual relationship. Connell and Korabik (2000) agreed that any direct or indirect sexual bribes that relates to job or individual benefits are part of sexual coercion.

The sexual coercion can be in many forms such as social desire, attacks, violation and distortion that threaten a person involuntarily involved in sexual relations (Erulkar, 2004). However, sexual coercion has been reported relatively rare occurrence compared to other form of sexual harassment. (Connell \& Korabik, 2000; Hogh, Conway, Clausen, Madsen, \& Burr, 2016).

\subsection{Unwanted Sexual Attention}

Richman et al. (1999) stressed that unwanted sexual attention involved undesirable touching and asking for dates continually. Jackson and Newman (2004) gauged that ladies are less averse to show receipt of undesirable sexual excitement as their proportion of male, and they are more inclined to demonstrate its (Bashir et al., 2013). Newman et al. (2003) inferred that undesirable sexual attention is more inclined towards high-wage labourers. Pradhan-malla (2005) investigated those inequalities between men and women has brought women to be forced in dealing with unwanted sexual attention. Furthermore, thisissue also has dispirited women to be competing for power.

Holland et al. (2016) also pointed that unwanted sexual attention take place when the harasser makes unwelcome or offensive sexual nature by touching or intended to establish romantic relationships especially with their co-workers. Whealin et al. (2002) also mentioned that unwanted sexual attention includes an uninvited verbal statement, motions, and other noncontact conducts made with respect to one's sexuality and 
physical presence. Additionally, Corr and Jackson (2001) argued that unwanted sexual attention not only by the unpleasant touching, but might involves spoken words or stares which might negatively affects the victim's work environment. According to Hogh et al. (2016) unwanted sexual attention can be from many sources such as colleagues, managers, customers and subordinated.

In Malaysia, a study by Ismail et al. (2007) revealed that disregard of their academic background; Malays implied this issue more seriously than other ethnic. Moreover, it revealed that sexual harassment occurred due to unprofessional working environment.

\subsection{Employee Job Satisfaction}

The crucial element of a successful organization is their employees. Job satisfaction is an essential element as it positively related with job performance.(Hira \& Waqas, 2012; Shmailan, 2016) Job satisfaction is defined as the indicator on how much employees like their job and influenced by one's job performance (Millán, Hessels, Thurik, \& Aguado, 2013). Furthermore, Fu and Deshpande (2014) described job satisfaction as a pleasant and positive feelings as the outcome of employee's job appraisal. While other researchers mentioned that work environment also contributed to employee satisfaction. In addition, job satisfaction is a capacity of the degree to which individual's needs are fulfilled in a job (Togia, Koustelios, \& Tsigilis, 2004).

In a similar vein, Norizan (2012) stated that job satisfaction has been an essential theme throughout the years. The pleasure of employees often associated with the remuneration and their genuine commitment in completing tasks (Fatt, Khin, \& Heng, 2010). However, Akpofure, Ikhifa, Imide, \& Okokoyo (2006) agreed that job satisfaction is associated with job accomplishment, constructive work values and how well the employees are inspired with their job and the task given.

Sexual harassment has been an issue that leads to employee's job dissatisfaction. Many studies found that sexual harassment show negative impact to job satisfaction. (Long et al., 2016; Merkin, 2008) As supported by Chan et al. (2008), sexual harassment not only reduce the level of job satisfaction, organizational commitment and job performance, but it also induced the victim to will experience psychological distress.

\section{Method}

This study was conducted by collecting empirical evidence through self-reported questionnaire. For the questions relating to sexual harassment, the questionnaire was adopted from Fitzgerald et al. (1988) which consisted of 21 items. However, for questions relating to employee job satisfaction, it was adopted from Taylor (1972) with 7 items. The questionnaire is divided into three parts. The first part was associated to the respondent's demographic profiles, the second part is related to the sexual harassment and the third part is questions related to employee job satisfaction. A total of 300 questionnaires were distributed to employee in automotive industry in North Region of Malaysia and in total 204 questionnaires were returned making for 68 $\%$ useable response rate.

All the variables were measured by turning the data collected from the survey into IBM SPSS version 24.0 and subsequently were analysed through descriptive method and Pearson Correlation analysis. Before that, reliability test was done to check the consistency of the questionnaire.

\section{Results and Discussion}

As clearly demonstrated in Table 1, this survey was dominated by female with $69 \%$ and male of $31 \%$. The highest percentage of respondents aged between 20 to 25 years old with $34 \%$ followed by age between 26 to 30 years and 31 to 25 with $23 \%$ respectively. Moreover $12 \%$ of the respondents aged between 36 to 40 years and the remaining respondents aged between 41 to 45 and above have a similar percentage of $4 \%$.

Majority of respondents are Malay (91\%), followed by Chinese (5\%) and Indian (3\%) while $1 \%$ are from other races in Malaysia. As for academic qualification, there are $60 \%$ of respondents with SPM qualification, $21 \%$ of respondents holding a diploma, $14 \%$ STPM qualification, only $4 \%$ of the respondents are university graduate while only $1 \%$ having a master's degree. The highest percentages of respondents are married $(52.5 \%)$ while $42 \%$ are single. The remaining $5 \%$ respondents are separated and divorced. 
Table 1. Demographic profile of respondents

\begin{tabular}{|llcc}
\hline Item & Categories & Frequency & Percentage (9) \\
\hline \multirow{4}{*}{ Age } & Male & 63 & 31 \\
& Female & 141 & 69 \\
& $20-25$ & 69 & 34 \\
& $26-30$ & 47 & 23 \\
Race & $31-35$ & 46 & 23 \\
& $36-40$ & 25 & 12 \\
& $41-45$ & 9 & 4 \\
Acad emic qualifications & 46 and above & 8 & 4 \\
& Malay & 185 & 91 \\
& Indian & 6 & 3 \\
& Chinese & 10 & 5 \\
& Others & 3 & 1 \\
& STPM & 122 & 60 \\
& Diploma & 28 & 14 \\
Status & Degree & 43 & 21 \\
& Master & 10 & 4 \\
& & 1 & 1 \\
& Single & 91 & 42 \\
& Married & 107 & 53 \\
& Divorced & 1 & 1 \\
& Separated & 5 & 4 \\
& & &
\end{tabular}

\subsection{Reliability Test}

In order to establish the consistency reliability of the independent variables and dependent variable, the Cronbach's Alpha value was obtained. All these variables can be referred to the Table 2. The reading for Cronbach's alpha for gender harassment is 0.887 , sexual coercion is 0.948 , unwanted sexual attention is 0.948 , and the coefficient reliability for job satisfaction is 0.948 . This shows that all variables exceeded the recommended level of 0.7 (George \& Mallery, 2005).

Table 2. Reliability Test

\begin{tabular}{|c|c|c|}
\hline Variable & Cronbach's Alpha & No of Item \\
\hline Sexual Harassment Variables & 0.961 & 21 \\
\hline Gender Harassment & 0.887 & 7 \\
\hline Sexual Coercion & 0.903 & 8 \\
\hline Unwanted Sexual Attention & 0.948 & 6 \\
\hline Job Satisfaction & 0.948 & 7 \\
\hline
\end{tabular}

The effect sexual harassment with employee job satisfaction as in Table 3 is partially supported the relationship between independent variables and dependent variable. Further, the result of this research show that sexual harassment in general and gender harassment has negatively related to the employee job satisfaction with correlation coefficient $\mathrm{r}=-0.143$ and $\mathrm{r}=-0.147$ respectively and there were significant at $\mathrm{p}=0.01$ level.

Based on the Table 4 below, since $73 \%$ of respondents were uncertain and unacquainted about the existence of the sexual harassment policy, this therefore exhibited a smaller effect on the correlation. However, there is considerable empirical evidence supporting these relationships (Fitzgerald et al., 1997; Fitzgerald, Gelfand, \& Drasgow, 1995; Willness et al., 2007) as the victims of sexual harassment report lower job satisfaction. Furthermore, (Cortina, 2001) reported that gender harassment from the subordinates and superiors were related to employee job satisfaction. 
Table 3. Correlation Analysis

\begin{tabular}{|c|c|c|c|c|c|c|}
\hline & & $\mathrm{SH}$ & $\mathrm{GH}$ & $\mathrm{SC}$ & USA & JS \\
\hline & Pearson Correlation & 1 & $.916^{* *}$ & $.920^{*+}$ & $.960^{*+}$ & $-.143^{\star}$ \\
\hline \multirow[t]{3}{*}{ SH } & Sig. (2-tailed) & & .000 & .000 & .000 & .041 \\
\hline & $\mathrm{N}$ & 204 & 204 & 204 & 204 & 204 \\
\hline & Pearson Correlation & $.916^{* *}$ & 1 & $.720^{+*}$ & $.860^{+*}$ & $-.147^{\star}$ \\
\hline \multirow[t]{3}{*}{$\mathrm{GH}$} & Sig. (2-tailed) & .000 & & .000 & .000 & .036 \\
\hline & $\mathrm{N}$ & 204 & 204 & 204 & 204 & 204 \\
\hline & Pearson Correlation & $.920^{* \star}$ & $.720^{\star \star}$ & 1 & $.830^{+*}$ & -.122 \\
\hline \multirow[t]{3}{*}{$\mathrm{SC}$} & Sig. (2-tailed) & .000 & .000 & & .000 & .083 \\
\hline & $\mathrm{N}$ & 204 & 204 & 204 & 204 & 204 \\
\hline & Pearson Correlation & $.960^{* *}$ & $.860^{* *}$ & $.830^{+1}$ & 1 & -.133 \\
\hline \multirow[t]{3}{*}{ USA } & Sig. (2-tailed) & .000 & .000 & .000 & & .057 \\
\hline & $\mathrm{N}$ & 204 & 204 & 204 & 204 & 204 \\
\hline & Pearson Correlation & $-.143^{\star}$ & $-.147^{\star}$ & -.122 & -.133 & 1 \\
\hline \multirow[t]{2}{*}{ JS } & Sig. (2-tailed) & .041 & .036 & .083 & .057 & \\
\hline & $\mathrm{N}$ & 204 & 204 & 204 & 204 & 204 \\
\hline
\end{tabular}

Meanwhile, sexual coercion, and unwanted sexual attention have no significant relationship with employee job satisfaction with correlation coefficient $(\mathrm{r}=-0.122$ and $\mathrm{r}=-0.133)$. This is also consistence with previous studies by Parker and Griffin (2002) and Antecol and Cobb-Clark, 2001).

Table 4. Policy of Sexual Harassment

\begin{tabular}{|c|c|c|c|}
\hline Scale & Frequency & Percent & Valid Percent \\
\hline Yes & 55 & 27 & 27 \\
\hline No & 111 & 54.4 & 54.4 \\
\hline Don't Know & 38 & 18.6 & 18.6 \\
\hline Total & 204 & 100 & 100 \\
\hline
\end{tabular}

The findings of this research found that there is a relationship between sexual harassment and employee job satisfaction. It shows that employees with experiences in sexual harassment are likely to feel bothered in their workplace affecting their job satisfaction. This findings was in line with the previous research conducted by (Long et al., 2016; Chan et al., 2008; Swarnalatha, 2013)

The management should emphasize more on sexual harassment issue in gaining more knowledge about individual who being harassed to achieve the goals by considering own strength and weaknesses safety policy in organization. As evident in Table 3, most of the employees were not aware on the sexual harassment policy by respective companies. Hence, companies are encouraged to be alert to this issue that might limit the employee's performance and limits their productivity level especially towards manufacturing workers. Moreover, the results of this study will serve as a guideline to improve safety, quality of work and job satisfaction of employee in company.

It is proposed for the future research that studies on men and women should be discussed separately for each gender. More insights on the effects of sexual harassment should be taken into consideration in future. In addition, the sample size should be extended and the population of other parts of region should be expanded.

Furthermore, the variable of employee job performance also should be explored in the future in order to gain more complete understanding regarding the relationship between sexual harassment and employee job satisfaction. Researcher also can extend this research by just choosing sample with respondents that experienced sexual harassment as to gain more exploratory outcomes. 


\section{Conclusion}

This study explores the relationship between sexual harassment (with three elements: gender harassment, sexual coercion and unwanted sexual attention) and employee job satisfaction in automotive industries in North region of Malaysia. The previous studies shown sexual harassment has negative correlation with job satisfaction. It shows that an employee that experienced sexual harassment will have an adverse effect on their job performance.

From this study, the data was collected and analysed from both genders in which the highest percentage is female respondents. However, from the results, only sexual harassment and gender harassment has negative relationships with job satisfaction. In addition, this study found that sexual coercion and unwanted sexual attention has no significant relationships with job satisfaction. It is also found that most of the employees are not aware and not informed with regard to the policy of sexual harassment.

References

Akpofure, R.-R., Ikhifa, O. G., Imide, O. I., \& Okokoyo, I. E. (2006). Job Satisfaction Among Educators in Colleges of Education in Southern Nigeria. Journal of Applied Sciences, 6(5), 1094-1098.

Alagappar, P. N., Lean, M. L., David, M. K., Ishak, Z., \& Ngeow, Y. M. (2011). 'You're So Hot! \{’\}: A Content Analysis of Sexual Harassment Among Hotel Employees. Humanities, Society and Culture, 20, 17-21.

Antecol, H., \& Cobb-Clark, D. (2001). Men, women, and sexual harassment in the US military. Gender Issues, 19(1), 3-18.

Bashir, U., Sharma, R., Jauhari, S., Singh, V., Karunanithy, K., Ponnampalam, A., ... Naqvi, H. (2013). A study on the effect of Stress on performance of employees in Commercial Bank of Ceylon in the Eastern Province. Impact of Stress on Employees Job Performance A Study on Banking Sector of Pakistan, 5(2), 87-96. http://doi.org/0975-5853

Bond, M. a, Punnett, L., Pyle, J. L., Cazeca, D., \& Cooperman, M. (2004). Gendered work conditions, health, and work outcomes. Journal of Occupational Health Psychology, 9(1), 28-45. http://doi.org/10.1037/1076-8998.9.1.28

Carr, P. L., Ash, A. S., Friedman, R. H., Szalacha, L., Barnett, R. C., Palepu, A., \& Moskowitz, M. M. (2012). $\mathrm{W}$ (C) 2000, 889-896.

Chan, D. K. S., Lam, C. B., Chow, S. Y., \& Cheung, S. F. (2008). Examining the job related, psychological and physical outcomes of workplace sexual harassment: a meta-analytic review. Psychology of Women Quarterly, 32(4), 362.

Compton, N. (2007). Against Hostile Environment Claims from Their Female And Male Employees: 2(1), 4148.

Corr, P., \& Jackson, C. (2001). Dimensions of perceived sexual harassment: effects of gender, and status/liking of protagonist. Personality and Individual Differences.

Cortina, L. (2001). Assessing sexual harassment among Latinas: Development of an instrument. Cultural Diversity and Ethnic Minority Psychology, 7(2), 164.

Erulkar, A. S. (2004). The Experience of Sexual Coercion Among Young People in Kenya. International Family Planning Perspectives, 30(4), 182-9. http://doi.org/10.1363/ifpp.30.182.04

Fatt, C. K., Khin, E. W. S., \& Heng, T. N. (2010). The impact of organizational justice on employee's job satisfaction: The Malaysian companies' perspectives. American Journal of Economics and Business Administration, 2(1), 56.

Fitzgerald, L. F., Drasgow, F., Hulin, C. L., Gelfand, M. J., \& Magley, V. J. (1997). Antecedents and Consequences of Sexual Harassment in Organizations: A Test of an Integrated Model. Journal of Applied PsychologyBorgida \& Fiske, 82(4), 578-589. http://doi.org/10.1037/0021-9010.82.4.578

Fitzgerald, L. F., Gelfand, M. J., \& Drasgow, F. (1995). Measuring Sexual Harassment: Theoretical and Psychometric Advances. Basic and Applied Social Psychology, 17(4), 425-445. http://doi.org/10.1207/s15324834basp1704 2.

Fitzgerald, L. F., \& Shullman, S. L. (1993). Sexual harassment: A research analysis and agenda for the 1990s. Journal of Vocational Behavior, 42(1), 5-27.

Fitzgerald, L. F., Shullman, S. L., Bailey, N., Richards, M., Swecker, J., Gold, Y., ... Weitzman, L. (1988). Sexual Experiences Questionnaire. The Incidence and Dimensions of Sexual Harassment in Academia and the Workplace, 32, 152-175. Retrieved from http://ezp- 
prod1.hul.harvard.edu/login?url=http://search.ebscohost.com/login.aspx?direct=true\&db=hpi\&AN $=$ HaPI-325284\&site $=$ ehost-live \&scope $=$ site

Fitzgerald, L., Swan, S., \& Magley, V. (1997). But was it really sexual harassment?: Legal, behavioral, and psychological definitions of the workplace victimization of women.

Frone, M. R. (2000). Interpersonal conflict at work and psychological outcomes: testing a model among young workers. Journal of Occupational Health Psychology, 5(2), 246. http://doi.org/10.1037/10768998.5.2.246

Fu, W., \& Deshpande, S. P. (2014). The Impact of Caring Climate, Job Satisfaction, and Organizational Commitment on Job Performance of Employees in a China???s Insurance Company. Journal of Business Ethics, 124(2), 339-349. http://doi.org/10.1007/s10551-013-1876-y

George, D., \& Mallery, P. (2005). SPSS for window step-by-step: A simple guide and reference (6th ed.). Boston, MA: Allyn \& Bacon.

Harvell, L. (2007). Political bias: a look into the college classroom.

Hersch, J. (2015). Sexual harassment in the workplace. IZA World of Labor. Retrieved from http://wol.iza.org/articles/sexual-harassment-in-workplace

Hira, A., \& Waqas, I. (2012). A Study of Job Satisfaction and IT's Impact on the Performance in the Banking Industry of Pakistan. International Journal of Business and Social Sciences, 3(19), 174-180.

Hogh, A., Conway, P. M., Clausen, T., Madsen, I. E. H., \& Burr, H. (2016). Unwanted sexual attention at work and long-term sickness absence: a follow-up register-based study. BMC Public Health, 16, 678. http://doi.org/10.1186/s12889-016-3336-y

Holland, K. J., Rabelo, V. C., Gustafson, A. M., Seabrook, R. C., \& Cortina, L. M. (2016). Sexual harassment against men: Examining the roles of feminist activism, sexuality, and organizational context. Psychology of Men \& Masculinity, 17(1), 17-29. http://doi.org/10.1037/a0039151

Housch, L., \& Collins, K. (1993). "To Hell with you, Charlie": The UAW has a long history of confronting sexual harassment, $1(20)$.

Hutagalung, F., \& Ishak, Z. (2012). Sexual Harassment: A Predictor to Job Satisfaction and Work Stress among Women Employees. Procedia - Social and Behavioral Sciences, 65(ICIBSoS), 723-730. http://doi.org/10.1016/j.sbspro.2012.11.190

Ismail, M. N., Lee, K. C., \& Chan, F. B. (2007). Factors Influencing Sexual Harassment in The Malaysian Workplace. Asian Academy of Management Journal, 12(2), 15-31. Retrieved from http://www.researchgate.net/publication/43655784_FACTORS INFLUENCING_SEXUAL_HAR ASSMENT IN THE MALAYSIAN WORKPLACE

Kenny, K., Samah, A., \& Othman, J. (2011). Sexual Harassment: Why Men Do It? A Study to Examine The Predictors That Leads Men To Sexually Harass. International Journal of Humanities ..., 1(12), 208217. Retrieved from http://www.ijhssnet.com/journals/Vol_1_No_12_September_2011/27.pdf

Leskinen, E. A. ., Rabelo, V. C., \& Cortina, L. M. (2015). Gender stereotyping and harassment: A "catch-22" for women in the workplace. Psychology, Public Policy, and Law, 21(2), 192-204. http://doi.org/http://dx.doi.org/10.1037/law0000040

Long, C. S., Lingyun, Z., Kowang, T. O., Fei, G. C., Khairuzzaman, W., \& Ismail, W. (2016). The Relationship between Sexual Harassment and Job Satisfaction in the Context of Retailing Industry in, 6(4), 1-19. http://doi.org/10.5296/ijhrs.v6i4.10077

Merkin, R. S. (2008). The Impact of Sexual Harassment on Turnover Intentions, Absenteeism, and Job Satisfaction : Findings from Argentina, Brazil and Chile, 10(2), 73-91.

Millán, J. M., Hessels, J., Thurik, R., \& Aguado, R. (2013). Determinants of job satisfaction: A European comparison of self-employed and paid employees. Small Business Economics, 40(3), 651-670. http://doi.org/10.1007/s11187-011-9380-1

Newman, M. A., Jackson, R. A., \& Baker, D. D. (2003). Sexual harassment in the federal workplace. Public Administration Review, 63 (4), 472-483.

Norizan, I. (2012). Organizational Commitment and Job Satisfaction Among Staff of.

O'Connell, C. E., \& Korabik, K. (2000). Sexual Harassment: The Relationship of Personal Vulnerability, Work Context, Perpetrator Status, and Type of Harassment to Outcomes. Journal of Vocational Behavior, 56(3), 299-329. http://doi.org/10.1006/jvbe.1999.1717 
Parker, S. K., \& Griffin, M. a. (2002). What is so bad about a little name-calling? Negative consequences of gender harassment for overperformance demands and distress. Journal of Occupational Health Psychology, 7(3), 195-210. http://doi.org/10.1037/1076-8998.7.3.195

Pradhan-malla, S. (2005). Sexual harassment in the workplace in asia, (May), 1-10.

Richman, J. A., Rospenda, K. M., Nawyn, S. J., Flaherty, J. A., Fendrich, M., Drum, M. L., \& Johnson, T. P. (1999). Sexual harassment and generalized workplace abuse among university employees: Prevalence and mental health correlates. American Journal of Public Health, 89(3), 358-363. http://doi.org/10.2105/AJPH.89.3.358

Sabitha, M., Asmak, A. R., \& Nur Sabrina, M. (2011). Differences in the Usage of Language and Attitudes Towards Sexual Harrasment At Workplace: a Gender Perspective, (Icm), 13-14.

Sabitha, M., \& Asmak, R. A. (2012). Experiences, Effects and Combating Sexual Harassment at Worplace: A Malaysian Case*. International Journal of Innovations in Business IJIB, 1(1).

Sabitha, M., Norul Huda, M. S., \& Roza, H. Z. (2013). Combating Sexual Harassment Towards a Healthier Workplace: Combating Sexual Harassment Towards a Healthier Workplace, (March), 180-191.

Sadruddin, M. (n.d.). Sexual Harassment at Workplace in Pakistan- Issues and Remedies about the Global Issue at Managerial Sector. Journal of Managerial Sciences Volume VII Number.

Shmailan, A. (2016). The relationship between job satisfaction, job performance and employee engagement: An explorative study. Issues in Business Management and Economics, 4(1) (January), 1-8. http://doi.org/10.15739/IBME.16.001

Swarnalatha, C. (2013). Original Article Workplace Harassment and Job Satisfaction: An Empirical Study Among Employees of Automotive Industries in India, 1(i), 1-6.

Taylor, J. and D. G. B. (1972). Survey of Organizations: A Machine-scored Standardized Questionnaire Investment. . University of Michigan.

Togia, A., Koustelios, A., \& Tsigilis, N. (2004). Job satisfaction among Greek academic librarians. Library and Information Science Research, 26(3), 373-383. http://doi.org/10.1016/j.lisr.2004.01.004

Whealin, J. M., Davies, S., Shaffer, A. E., Jackson, J. L., \& Love, L. C. (2002). Family context and childhood adjustment associated with intrafamilial unwanted sexual attention. Journal of Family Violence, 17(2), 151-165. http://doi.org/10.1023/A:1015009501050

Willness, C. R., Steel, P., \& Lee, K. (2007). A meta-analysis of the antecedents and consequences of workplace sexual harassment. Personnel Psychology, 60(1), 127-162. http://doi.org/10.1111/j.1744$\underline{6570.2007 .00067 . x}$

Yusuf, N. (2010). Experience of Sexual Harrassment at work by Female Employees in a Nigerian Work Environment - Noa_0.pdf. 